\title{
Fate of Francisella noatunensis, a pathogen of Atlantic cod Gadus morhua, in blue mussels Mytilus edulis
}

\author{
Ingvild H. Wangen ${ }^{1,3}$, Egil Karlsbakk ${ }^{1}$, Ann Cathrine B. Einen ${ }^{1}$, Karl F. Ottem ${ }^{2}$, \\ Are Nylund $^{2}$, Stein Mortensen ${ }^{1, *}$ \\ ${ }^{1}$ Institute of Marine Research, PO Box 1870, Nordnes, 5817 Bergen, Norway \\ ${ }^{2}$ Department of Biology, University of Bergen, Bergen, Norway \\ ${ }^{3}$ Present address: Lillesand kommune v/VAR, PO Box 23, 4791 Lillesand, Norway
}

\begin{abstract}
Francisellosis, caused by the bacterium Francisella noatunensis, is one of the most severe diseases affecting farmed cod, and has caused great economic loss for the cod farming industry in Norway. We studied the fate of $F$. noatunensis in the marine environment, focusing on the role of blue mussels. In experimental challenges, waterborne F. noatunensis was rapidly filtered by the blue mussel and transported to the digestive diverticulae. The bacteria passed through the entire digestive system. Intraperitoneal injection of cod with suspensions prepared from faeces collected from challenged mussels resulted in the development of francisellosis in the recipients, demonstrating that some bacteria were alive and infective when shed in mussel faeces. Bacterial clearance from the mussels was relatively fast, and no evidence was found, suggesting that the bacterium is capable of persisting or multiplying in the mussel tissues. A cohabitation experiment with cod and mussels previously exposed to $F$. noatunensis did not lead to infection in cod. A direct transmission from contaminated mussels to cod was thus not demonstrated; however, faeces particles with infective bacteria may play a role in the transmission of the bacterium in marine food chains.
\end{abstract}

KEY WORDS: Francisella $\cdot$ Mussels $\cdot$ Cod $\cdot$ Persistence $\cdot$ Clearance $\cdot$ Transmission

\section{INTRODUCTION}

In 2004 a new systemic, granulomatous disease affecting large cod in western Norway was described (Nylund et al. 2006, Olsen et al. 2006). The causative agent was identified as an intracellular bacterium from the genus Francisella. The valid name is Francisella noatunensis ssp. noatunensis (Syns. F. piscicida; F. philomiragia ssp. noatunensis) (Ottem et al. 2009). Francisellosis in cod is associated with reduced growth, mortalities, reduced quality, and elevated discard rates at slaughter, with corresponding economic losses (Nylund et al. 2006). Knowledge of transmission mechanisms of F. noatunensis is scarce; however, horizontal transmission by cohabitation of cod kept at high temperatures has been shown in laboratory experiments (Nylund et al. 2006, Mikalsen et al. 2009). Field observations seem to support these findings, as the prevalence within infected stocks is often high (Colquhoun et al. 2008, Ottem et al. 2008). Little information is available on the survival of $F$. noatunensis in the marine environment (Duodu \& Colquhoun 2010). However, bacteria from the Francisella genus are found to be widespread in the environment and have been isolated from water and mud where they can persist for at least a year (Forsman et al. 1995, Broekhuijsen et al. 2003, Berrada \& Telford 2010). 
Free or particle-bound Francisella noatunensis may be taken up by filter feeders in the marine environment. We have focused on blue mussels Mytilus edulis, which are widespread in the marine environment and common on farming facilities in Norway. Bivalves filter large volumes of water and retain particles depending on size (Birkbeck \& McHenery 1982, Riisgard 1988). The dynamics of survival of human faecal bacteria have been thoroughly studied in bivalves from sewage-polluted seawater, and results show that $48 \mathrm{~h}$ in non-contaminated water at temperatures $>5^{\circ} \mathrm{C}$ is usually enough to reduce the concentration of bacteria such as Escherichia coli to low levels. Clearance or inactivation of ingested viruses will generally require more time, and may persist for several days (Richards 1988, Doré \& Lees 1995).

Both viral and bacterial fish pathogens have been isolated from bivalves (Meyers 1984, Mortensen et al. 1990), and it has been speculated whether bivalves may act as reservoirs for such disease agents. It has been shown that bivalves may act as biofilters, removing bacteria from the water. For instance, blue mussels may have a beneficial effect in a net pen environment by reducing the amount of the kidney disease bacterium Renibacterium salmoninarum present (Paclibare et al. 1994). Bivalves are also capable of retaining fish pathogenic viruses, but persistence periods vary greatly, presumably reflecting differences in the robustness of the viruses (Mortensen et al. 1992, Skår \& Mortensen 2007).

Francisella noatunensis was detected in blue mussels Mytilus edulis collected close to cod farms experiencing francisellosis (Ottem et al. 2008). Blue mussels on or near cod-rearing pens may remove and accumulate the bacterium from water. The aim of the present study was to examine the fate of F. noatunensis in the mussels, and to clarify their epizootiological importance.

\section{MATERIALS AND METHODS}

The Francisella noatunensis ssp. noatunensis strain (GM2212) used throughout this experiment was originally isolated from the head kidney of farmed Atlantic cod suffering from francisellosis (Nylund et al. 2006). Bacteria were grown on cysteine heart agar (Dif $\mathrm{CO}^{\mathrm{TM}}$ ) with $5 \%$ chocolatized sheep blood (CHAB) at $20^{\circ} \mathrm{C}$. The antiserum used for the detection of $F$. noatunensis was originally produced against F. noatunensis strain GM2212 (Ottem et al. 2007). The antiserum had a titer of 1:600000 and was not absorbed.
Blue mussels Mytilus edulis were collected in Svindal, Lindås, north of Bergen, Norway, in April 2008. There are no fish farms in the vicinity of the collection site. Mussels with a shell length of approximately $5 \mathrm{~cm}$ were selected and kept in a storage tank with running filtered seawater at approximately $9^{\circ} \mathrm{C}$ at the Institute of Marine Research (IMR).

Cod used in Expts 1 and 2 originated from Parisvatnet, a semi-extensive cod cultivation facility belonging to IMR, located in Øygarden, west of Bergen, Norway. These fish had been dip-vaccinated against vibriosis (Alpha-Marine) when they were approximately $5 \mathrm{~g}$ in weight. The fish used in the cohabitation experiment were unvaccinated but received prophylactic treatment against vibriosis with oxolinic acid in-feed 3 mo prior to the experiment. At the start of the Expts ( 1 and 2) the cod had a mean weight of $170 \mathrm{~g}$. They were kept in 2501 tanks, with a water flow of $101 \mathrm{~min}^{-1}$, a temperature of $14^{\circ} \mathrm{C} \pm 0.1$, salinity of 34.5 , and oxygen saturation of 7.5 to $8.5 \mathrm{mg} \mathrm{l}^{-1}$.

The cod in Expt 3 (mean weight $142 \mathrm{~g}$ ) were kept in 801 tanks, with a water flow of $8.01 \mathrm{~min}^{-1}$, salinity of 34.5 , and a temperature of $9^{\circ} \mathrm{C} \pm 0.1$ for 1 mo before the temperature was raised to $14^{\circ} \mathrm{C} \pm 0.1$ for 2 mo. Samples from the kidney of $10 \mathrm{cod}$ from the stock used in Expts 1 and 2, and 10 cod from the stock used in Expt 3 were analysed for the presence of Francisella noatunensis by real-time RT-PCR (Fc50 assay; Ottem et al. 2008) prior to the experiments. All were found negative.

At autopsy the fish were terminally anesthetised by benzocaine and the abdominal cavity was carefully opened and inspected. Macroscopic signs of disease were registered. Pieces of the anterior kidney $(\sim 60 \mu \mathrm{g})$ were stored at $-80^{\circ} \mathrm{C}$ until analysis (realtime RT-PCR). From cod in Expt 3, additional samples from spleen, heart, kidney, and visible granulomas in liver were fixed in $4 \%$ phosphate-buffered formaldehyde (48 h) for histology.

\section{Expt 1. Viability of Francisella noatunensis in mussels}

Blue mussels $(n=60)$ were added to 2 aquaria with seawater (30 l) located in a temperature-controlled room $\left(8^{\circ} \mathrm{C}\right)$. Francisella noatunensis was grown on CHAB agar plates for $12 \mathrm{~d}$ and suspended in $800 \mathrm{ml}$ autoclaved seawater. This suspension was then added to one of the tanks containing mussels ('exposed group'), the second acting as control. After mixing, a water sample $(1 \mathrm{ml})$ was removed and subsequently used to estimate the concentration of $F$. noatunensis in the aquarium (real-time RT-PCR) to 
$1.9 \times 10^{9}$ bacteria $\mathrm{ml}^{-1}$ (see 'Estimation of concentration of bacteria in inocula'). After $6 \mathrm{~d}$ exposure, the mussels were removed and transferred to a flowthrough system where they were kept for $5 \mathrm{~d}$ before being sampled. Digestive gland tissues from 5 mussels from each group were homogenised in phosphate-buffered saline (PBS, Calbiochem $\left.{ }^{\circledR}\right)(1 / 10$ dilution by volume), and centrifuged $\left(54 \times g, 2 \mathrm{~min}, 20^{\circ} \mathrm{C}\right.$ and $149 \times g, 1 \mathrm{~min}, 20^{\circ} \mathrm{C}$ ) to remove particulate material. The supernatant was further diluted 1/5 in PBS for use as inocula. Real-time RT-PCR testing of subsamples $(0.1 \mathrm{ml})$ from the inocula detected $F$. noatunensis rRNA in the inoculum from exposed mussels (cycle threshold: $C_{\mathrm{t}}=29.7, \sim 1.3 \times 10^{4}$ bacteria). However, the inoculum from the unexposed mussels was also positive with real-time PCR, with $C_{t}$ $=30.9$ (in the standard curve corresponding to $\sim 6 \times$ $10^{3}$ bacteria). Ten benzocaine-sedated cod were injected intraperitoneally with $0.2 \mathrm{ml}$ of each suspension and kept for $9 \mathrm{wk}$ at $14^{\circ} \mathrm{C}$ before they were killed and sampled from the anterior kidney for real-time RT-PCR analysis as described above.

\section{Expt 2. Viability of Francisella noatunensis shed with mussel faeces}

Two 301 aquaria were prepared as described in Expt 1, each with 60 blue mussels. Francisella noatunensis was grown and suspended as described above (Expt 1), and added to one tank, the second acting as control. The F. noatunensis concentration in the tank was estimated from a water sample (real-time RT$\mathrm{PCR}$ ) to $1.3 \times 10^{8}$ bacteria $\mathrm{ml}^{-1}$. After $3 \mathrm{~d}$ the mussels from each aquarium were moved to 2 new tanks in a flow-through system where they were left for $5 \mathrm{~d}$ before the tank and mussels were flushed and thoroughly washed with seawater to remove all faeces particles. The following day (Day 0), faeces were collected from the contaminated mussels $(502 \mathrm{mg}$ wet wt) and the control mussels (511 mg) and suspended in tubes with $4.5 \mathrm{ml}$ PBS. These faeces samples may also contain pseudo-faeces since these could not be distinguished. The tubes were thoroughly vortexed and left for $2 \mathrm{~min}$ in order to let the particles sediment. The supernatants were then removed and further diluted 1:5 in PBS. Real-time RT-PCR testing of a subsample $(0.1 \mathrm{ml})$ from the final inoculum confirmed presence of $F$. noatunensis $\left(C_{\mathrm{t}}=27.1\right.$, corresponding to $\sim 6 \times 10^{4}$ bacteria). The subsample from the control group faeces inoculum was also positive $\left(C_{\mathrm{t}}=31.7\right.$, corresponding to $\sim 3.8 \times 10^{3}$ bacteria). Ten cod in each group were sedated using benzocaine and intraperi- toneally injected with $0.2 \mathrm{ml}$ of the faeces-inocula. After $9 \mathrm{wk}$ at $14^{\circ} \mathrm{C}$, the fish were killed and kidney samples collected for real-time RT-PCR as described above. Additional faeces samples were collected at Days 0,7 , and 14 after transfer to flow-through system. These were analysed with real-time RT-PCR for $F$. noatunensis but were not injected into cod.

\section{Expt 3. Cohabitation of cod with contaminated mussels}

Blue mussels $(n=60)$ were added to each of 4 (80 l) tanks (Nos. 1 to 4 ) with continuous water supply $\left(8.01 \mathrm{~min}^{-1}\right)$. A Francisella noatunensis suspension in $150 \mathrm{ml}$ seawater was prepared from CHAB agar plates, washed, centrifuged for $10 \mathrm{~min}$ at $4300 \times g$, resuspended in autoclaved seawater $(28 \%$ ), and diluted giving a concentration of $1.4 \times 10^{7}$ bacteria $\mathrm{ml}^{-1}$ (colony forming units [CFU] count). This suspension (500 $\mathrm{ml} \mathrm{tank}^{-1}$ ) was gradually added to 3 tanks (Nos. 1,2 and 4) for a period of $1 \mathrm{~h}$, to avoid interruption in feeding by the mussels due to the addition. The blue mussels were then left to filter for $4 \mathrm{~h}$ until the water flow was restored. The remaining tank (No. 3) was untreated and acted as control in the cohabitation experiment.

The tanks and mussels were thoroughly flushed and washed prior to adding of cod to remove all faecal particles. Cod were added to 3 of the tanks (Nos. 1 to 3), beginning at $11 \mathrm{~d}$ post-mussel exposure in the control tank (No. 3) and one exposed tank (No. 1), and at Day 22 in a second exposed tank (No. 2). Mussels from the fourth tank were sampled for histology and real-time RT-PCR analysis at Days 1, 3, 7, 11, 22, 46, 69, and 113, 5 mussels at each sampling. Cross sections of $0.5 \mathrm{~cm}$ from the digestive system and gills of the blue mussels were cut and fixed in Davidson's fixative (48 h) (Shaw \& Battle 1957).

$\mathrm{Cod}$ and blue mussels were kept together at $9^{\circ} \mathrm{C}$ for $4 \mathrm{wk}$ before the mussels were removed and the temperature raised to $14^{\circ} \mathrm{C}$ to accelerate any Francisella noatunensis infection contracted. The blue mussel group kept for histology was kept at $9^{\circ} \mathrm{C}$ throughout the entire experiment in order to avoid mussels spawning. The fish were killed after $13 \mathrm{wk}$, when they were sampled and analysed with real-time RT-PCR.

\section{Extraction of total RNA}

Total RNA was extracted using the RNeasy Mini Kit (Qiagen ${ }^{\circledR}$ ) according to the manufacturer's 
recommendations for tissue samples. The extreme halophile archaea Halobacterium salinarum (strain DSM 3754/ATCC 33171) was used as an exogenous control for the real-time RT-PCR assays (Nylund et al. 2010). The archaea were aliqoted at the cultivated concentration and stored at $-80^{\circ} \mathrm{C}$. Of this stock, $2 \mu \mathrm{l}$ were added to all samples prior to RNA extraction. RNA quantity from the tissue samples were measured using a Nano Drop ND-1000 spectrophotometer (Thermo Scientific) and diluted to a concentration

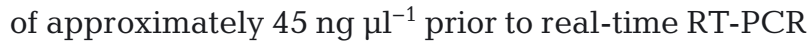
analysis. RNA quality was analysed from a selection of 12 samples, 6 from cod tissue and 6 from blue mussel using a RNA 6000 Nano Assay Kit with the Agilent Bioanalyzer 2100.

\section{Real-time RT-PCR}

The real-time RT-PCR assay Fc50-specific for the 16S rRNA from Francisella noatunensis was used (Ottem et al. 2008). The elongation factor from cod (EF1AA) was used as an internal control (Olsvik et al. 2006) in addition to the external control Halobacterium salinarum (Sal-assay) (Nylund et al. 2010). Negative template controls (NTC), negative controls from the RNA extraction and one positive control (GM2212, $\left.C_{\mathrm{t}}=\sim 29\right)$ for $F$. noatunensis were included in all runs.

The Verso ${ }^{\text {TM }} 1$-step QRT-PCR ROX Kit (Thermo Scientific) was used for the real time RT-PCR assays. The reaction mixture was as follow; $6.25 \mu \mathrm{l} 2 \times 1$-step QPCR Rox Mix (Verso), $0.125 \mu$ l Enzyme mix, $0.625 \mu \mathrm{l}$ RT-enhancer, optimized concentrations of primers and probes depending on assay, and $2 \mu \mathrm{l}$ of total RNA (90 ng for tissue samples) as template. The total volume was adjusted to $12.5 \mu$ by adding diethylpyrocarbonate (DEPC) $\mathrm{H}_{2} \mathrm{O}$ (RNAse-free water). ABI 7500 sequence detection system (Applied Biosystems) was used to perform the analysis. The reaction was $15 \mathrm{~min}$ at $50^{\circ} \mathrm{C}, 15 \mathrm{~min}$ at $95^{\circ} \mathrm{C}, 45$ cycles at $95^{\circ} \mathrm{C}$ for $15 \mathrm{~s}$, followed by $1 \mathrm{~min}$ at $60^{\circ} \mathrm{C}$. Threshold values were set at 0.003 for the FC50, 0.008 for EF1AA, and 0.001 for Halobacterium Salinarum, and all samples were run in duplicate.

The efficiencies for the 3 assays were tested using a 10-fold dilution series (Table 1). The RNA template was diluted 1/10 using yeast transfer-RNA (t-RNA) solution (20 ng $\mathrm{ul}^{-1}$ ) (Invitrogen) as it has been shown to stabilize the kinetics during the dilution series (Ståhlberg et al. 2004). All samples were analyzed in triplicate. The standard curves created by the ABI 7500 sequence detecting system were used. The amplification efficiency was calculated using the formula: $\left(10^{-1 / \text { slope }}\right)-1$. The sensitivity for the Fc50 assay is $C_{\mathrm{t}}=37.5$ (Ottem et al. 2008).

\section{Estimation of concentration of bacteria in inocula}

Bacteria grown on 2 CHAB agar plates (12 d) were washed off with $3 \mathrm{ml}$ of autoclaved seawater (28\%). This $3 \mathrm{ml}$ suspension was further diluted in a 10-fold dilution series in 9 tubes, and the $10^{-2}$ dilution were counted 3 times in a counting chamber (Improved Neubauer). The $10^{-2}$ dilution contained $1.8 \times 10^{8}$ bacteria $\mathrm{ml}^{-1}$ corresponding to ca. $1.8 \times 10^{10} \mathrm{ml}^{-1}$ in the undiluted sample. The $10^{-6}, 10^{-7}, 10^{-8}$ tubes were plated out on $\mathrm{CHAB}$ and $\mathrm{CFU}$ were counted after $2 \mathrm{wk}$. The CFU count estimated a concentration of $2 \times$ $10^{10}$ bacteria $\mathrm{ml}^{-1}$ in the undiluted sample. The entire dilution series was stored at $-80^{\circ} \mathrm{C}$ and analysed with real-time RT-PCR in duplicates. A standard curve was created based on these results and used in the estimation of dosage in the inocula of the different experiments: number of bacteria $N_{\text {bact }} \approx \mathrm{e}^{\left(C_{\mathrm{t}}-45.451\right) /-1.669}$, $\mathrm{R}^{2}=0.9914$ (Pearson's product-moment correlation).

\section{Immunohistochemistry}

Dehydration and immunostaining of the formalinfixed blue mussel and cod samples were performed according to Sandlund et al. (2006). The primary polyclonal rabbit antiserum: anti-Francisella was diluted 1:2000 in Tris-buffer (0.05 M, pH 7.6) with $2.5 \%$ BSA (Sigma). Avidin-biotin-alkaline phosphatase complex reaction kit (Vectastain ${ }^{\circledR}$ universal ABC-AP Kit AK 5200, Vector Lab) and Fuchsin substrate-chromagen (KO624, Dako A/S) were used to visualize positive staining (bright red). At each staining, a positive control sample (spleen from cod suffering from francisellosis) was used. A Leica DMBE microscope equipped with a Micro publisher 5.0 RTV (Q-Imaging) was used to examine and photograph the preparations.

\section{RESULTS}

\section{Expt 1}

A total of 7 out of $10 \mathrm{cod}$ injected with homogenate from mussels $11 \mathrm{~d}$ after the exposure to Francisella noatunensis showed internal macro- 
scopic signs consistent with francisellosis when examined 9 wk post-challenge. Macroscopic signs observed were granulomas in liver, spleen, and the wall of the abdominal cavity. All 7 cod were positive for $F$. noatunensis when analysed by real-time RTPCR $\left(C_{\mathrm{t}}=26.2\right.$ to 38.8$)$. The 3 cod lacking visible granulomas were $F$. noatunensis-negative with realtime RT-PCR. The control group, injected with tissue homogenate from unexposed blue mussels, was negative when tested for $F$. noatunensis with real-time RT-PCR $(\mathrm{n}=9)$. One fish in this group was killed due to eye damage.

\section{Expt 2}

All cod in the group injected with inocula prepared from blue mussel faeces collected $9 \mathrm{~d}$ after the exposure to Francisella noatunensis were positive when analysed with the $F$. noatunensis real-time RT-PCR assay $\left(C_{\mathrm{t}}=25.1\right.$ to 33.9$)$. The control group, injected with inocula from faeces from unexposed blue mussels, was negative $(\mathrm{n}=9)$. One cod in the control group died shortly after injection. Real-time RT-PCR analyses of blue mussel faeces samples collected at Days 0,7 , and 14 from the exposed mussels were positive for $F$. noatunensis $\left(C_{\mathrm{t}}=29.5,35.7\right.$, and 33.9, respectively).

\section{Expt 3}

All groups of cod cohabiting with blue mussels previously exposed to Francisella noatunensis (11 or $22 \mathrm{~d}$ earlier) or unexposed control mussels were negative for $F$. noatunensis when analysed with realtime RT-PCR at 13 wk post challenge. However, several fish in these groups developed disease and were removed. These included fish with skin and fin haemorrhages (4 in the control group and 1 and 4 fish in the exposed groups). Several fish in the exposed group showed granulomas in the liver and spleen. No aetiological agent was identified, and both immunohistochemistry and real-time PCR for F. noatunensis were negative.

The number of exposed mussels positive for Francisella. noatunensis decreased during the $113 \mathrm{~d}$ they were sampled. Also, the normalized expression in positive mussels decreased with time (Spearman's rank correlation coefficients, $\mathrm{p}<0.05)$. However, some of the unexposed mussels also showed positive signals, albeit generally close to or above the cut-off value of $C_{\mathrm{t}}=37.5$.

\section{Immunohistochemistry of blue mussels exposed to Francisella noatunensis (Expt 3)}

In the unexposed control mussels, there was no positive immune staining in the digestive diverticulae. An unspecific diffuse light red staining of the brush border of the intestinal epithelia was observed in most specimens (Fig. 1). In addition, focal aggregates of brown cells with a red-brownish granulation were seen. In 4 specimens, small, stained particles were observed inside haemocytes.

The challenged mussels showed a clear red immune staining, different from the control mussels, in the digestive cells in the digestive diverticulae (Figs. 2 \& 4). One day after exposure to Francisella noatunensis, positive immune-staining was observed as red particles or areas in these digestive cells in 3 out of 5 mussels sampled. This staining was not observed in other tissues. At Day 3, positive staining was observed in all 5 specimens. The number of positive particles, as well as the intensity of the staining, was variable. At Day 7, a moderate but variable staining was observed in the digestive diverticulae (Fig. 4). In one specimen a strong positive staining was observed in the lumen of a primary digestive duct (Fig. 3). At Day 11, 4 out of 5 specimens revealed a positive but variable staining. Two of these also showed a few positive particles in the intestinal lumen. At Day 22, red coloration was not observed in the digestive epithelia, but 2 specimens had a clear red coloration in the stomach epithelia. In one of these, coloured granules were observed inside haemocytes. At Day 46 a few positive particles were observed in haemocytes of one specimen. In other specimens sampled at Day 46 and all those sampled at Day 69, no immunohistochemical staining different from the control specimens was observed. Symbiotic ciliates in the gills of the challenged mussels were strongly positive (Fig. 7), while those in the control mussels were unstained (Fig. 6). The challenged mussels showed the same diffuse staining of

Table 1. Slope, intercept, $\mathrm{R}^{2}$, and efficiency $(E)$ for the 3 realtime RT-PCR assays used. The Fc50 assay detects Francisella noatunensis 16S rRNA, Sal detects Halobacterium salinarum 16S rRNA, and EF1AA the cod elongation factor $1 \mathrm{~A}$ mRNA

\begin{tabular}{|lcccc|}
\hline Assay & Slope & Intercept & $\mathrm{R}^{2}$ & $E$ \\
\hline Fc50 & -3.3865 & 13.8941 & 0.9919 & 0.9737 \\
Sal & -3.3553 & 15.9541 & 0.9987 & 0.9863 \\
EF1AA & -3.3529 & 10.5820 & 0.9996 & 0.9872 \\
\hline
\end{tabular}



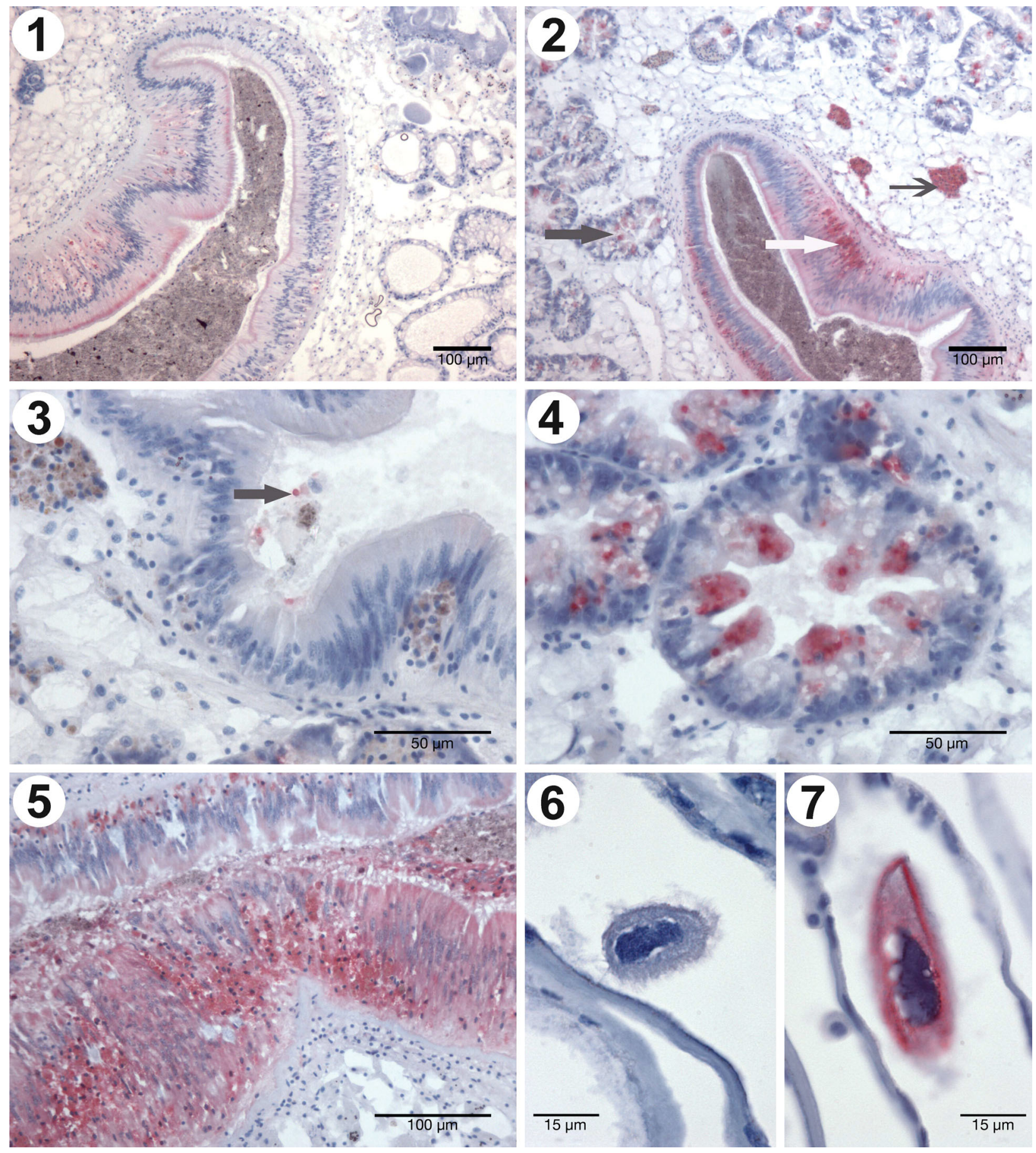

Figs. 1-7. Francisella noatunensis infected Mytilus edulis. Immunohistochemical (IHC) staining of paraffin sections from blue mussels. Avidin-biotin-alkaline phosphatase method, primary polyclonal rabbit antisera: anti-F. noatunensis subsp. noatunensis, and Shandon haematoxylin counterstained. Positive IHC staining is visualized by red colour. Figs. $1 \& 2$. Sections of intestine, storage tissues, and digestive diverticulae. Fig. 1. Unchallenged, negative control mussel. A diffuse red staining is observed in the epithelial cells lining the intestine. No staining observed in the digestive diverticulae. Some red colouration was also seen in individual cells, presumably haemocytes. Fig. 2. Day 7 post-exposure (PE) to F. noatunensis. A strong red colouration indicating the presence of the bacterium is observed both in the intestinal epithelium (white arrow), digestive cells of the diverticulae (black arrow) and in clusters of haemocytes in the storage and connective tissue (small arrow). Fig. 3. Section of primary digestive duct Day 7 PE showing positive colouration of contents (arrow). Fig. 4. Digestive cells in the diverticulae from Day 7 PE, with strong staining. Fig. 5. Stomach epithelia exhibiting haemocyte activity and strong positive immune staining at Day 7 PE. Figs. 6 \& 7. Symbiotic ciliates in the gills of unexposed (Fig. 6) and exposed (Fig. 7) blue mussels, Day 1 PE, showing strong colouration in the cytoplasm of ciliate exposed to the bacterium indicating substantial F. noatunensis uptake.

Scale bars in Figs. 1, 2, \& $5=100 \mu \mathrm{m}$; in Figs. $3 \& 4=50 \mu \mathrm{m}_{\text {; }}$ in Figs. $6 \& 7=15 \mu \mathrm{m}$ 
Table 2. Francisella noatunensis infecting Mytilus edulis. Detection of F. noatunensis in blue mussels exposed to the bacterium in aquaria, at different sampling times post-exposure, using immunohistochemistry (IHC) or real-time RT-PCR. A distinction is made between cycle threshold $\left(C_{\mathrm{t}}\right)$ values below and above 37.5, since higher values are not generally reproducible. Most samples from which $C_{\mathrm{t}}$ values above 37.5 are indicated were positive in one replicate only. Localization of positive IHC is explained in 'Immunohistochemistry of blue mussels exposed to Francisella noatunensis' and shown in Figs. 1 to 7

\begin{tabular}{|c|c|c|c|c|c|c|}
\hline \multirow{3}{*}{$\begin{array}{l}\text { Sample } \\
\text { day }\end{array}$} & \multirow{3}{*}{$\begin{array}{c}\text { IHC } \\
\text { No. positive/ } \\
\text { no. examined }\end{array}$} & \multirow{3}{*}{$\begin{array}{l}\text { No. negative/ } \\
\text { no. examined }\end{array}$} & \multirow{2}{*}{\multicolumn{2}{|c|}{$\begin{array}{l}\text { Real-time RT-PCR } \\
\text { No. of positive signals }\end{array}$}} & \multirow{2}{*}{\multicolumn{2}{|c|}{$C_{\mathrm{t}}$ range }} \\
\hline & & & & & & \\
\hline & & & $<37.5$ & $>37.5$ & $<37.5$ & $>37.5$ \\
\hline \multicolumn{7}{|c|}{ Exposed mussels } \\
\hline 1 & $3 / 5$ & $0 / 5$ & 4 & 1 & $33.1-35.9$ & 38.9 \\
\hline 3 & $5 / 5$ & $0 / 5$ & 4 & 1 & $35.7-37.5$ & 38.1 \\
\hline 7 & $5 / 5$ & $1 / 5$ & 1 & 3 & 36.4 & $38.1-38.7$ \\
\hline 11 & $4 / 5$ & $1 / 5$ & 2 & 2 & $35.8-37.3$ & $39.6-39.8$ \\
\hline 22 & $3 / 5$ & $3 / 5$ & 1 & 1 & 33.2 & 39.1 \\
\hline 69 & $0 / 5$ & $5 / 5$ & 0 & 0 & & \\
\hline 113 & $0 / 5$ & $4 / 5$ & 1 & 0 & 34.8 & \\
\hline \multicolumn{7}{|c|}{ Unexposed mussels } \\
\hline 0 & $0 / 5$ & $3 / 5$ & 1 & 1 & 27.4 & 39.4 \\
\hline 88 & $0^{\mathrm{a}} / 5$ & $3 / 10$ & 3 & 4 & $31.1-35.0$ & $38.0-39.3$ \\
\hline 113 & $0^{\mathrm{a} / 5}$ & $2 / 5$ & 2 & 1 & $37.1-37.4$ & 39.1 \\
\hline
\end{tabular}

brush-borders in stomach and intestine, and the brownish, focal granulation observed in unexposed control specimens (cf. Figs. 1 \& 2).

\section{Real-time RT-PCR of control mussels in Expts 1 to 3}

When the control mussels were tested for Francisella noatunensis with the Fc50 assay, some individuals produced positive signals (Table 2). The non template control (NTC) and negative purification controls were all negative. Subsequent attempts were made to determine the cause of these results through amplifying bacterial $16 \mathrm{~S}$ on some of the samples with the lowest $C_{\mathrm{t}}$ values, followed by nested PCR with several combinations of primers designed to be Francisella-specific (Nylund et al. 2006). Products giving appropriately sized bands were sequenced, revealing various marine Gammaproteobacteriae (Alteromonadaceae, Alcanivoracaceae, Legionellaceae) but no bacteria belonging or closely related to the genus Francisella.

\section{DISCUSSION}

There is little information available on the presence and survival of Francisella noatunensis in the marine environment, and the only known natural reservoir is infected cod (Ottem et al. 2008, Duodu \& Colquhoun 2010, Colquhoun \& Duodu 2011, Zerihun et al. 2011). F. noatunensis has been detected in wild cod in the southern parts of Norway and from the Swedish west coast, both as clinically diseased fish and as healthy 'carriers' found positive for the bacterium when examined with real-time RT-PCR (Alfjorden et al. 2006, Ottem et al. 2008). The bacterium has been detected in several unrelated wild marine fishes, blue mussels Mytilus edulis. and in edible crab Cancer pagurus with real-time RT-PCR, but in all cases in small amounts precluding further confirmation of identity by culturing or sequencing. Kamaishi et al. (2010) reported Francisella sp. infecting a molluscan (abalone Haliotis gigantea) in Japan. Such observations may indicate that $F$. noatunensis is widespread in the environment in both fish and invertebrates (Ottem et al. 2008).

The mechanism by which Francisella noatunensis is shed into water by infected cod is not known, but infections are readily obtained in cohabitation challenges (Nylund et al. 2006, Mikalsen et al. 2009). Blue mussels are very common in the marine environment and feed on small particles in water, which also include bacteria e.g. (Zobell \& Feltham 1938, McHenery \& Birkbeck 1985, Prieur et al. 1990) The fate of the bacteria in the bivalves is dependent on their ability to resist the enzymes present in the digestive system of the bivalve, and it has been shown that lyzosyme resistant bacteria are rejected without degradation (Birkbeck \& McHenery 1982). Bivalves may therefore function either as a biological filter or a reservoir for different bacteria. 
We have shown that blue mussels filter Francisella noatunensis from the water. Immunohistochemistry of the digestive system of the blue mussels showed the presence of bacteria in the digestive compartments of the diverticulae, as well as in the lumina of ducts and intestine, illustrating the passage of bacteria through the entire digestive system. Cod that were injected with tissue homogenate from the digestive gland $11 \mathrm{~d}$ after uptake of bacteria developed francisellosis, thus verifying the presence of Francisella and showing that bacteria in the digestive system of the blue mussels were alive and infective at this time. However, IHC samples taken $22 \mathrm{~d}$ after exposure revealed only a diffuse unspecific coloration. After this point of time, no bacteria could be observed with IHC. Real-time RT-PCR analyses targeting 16s rRNA indicates a clearance of $F$. noatunensis within approximately $3 \mathrm{wk}$ after uptake and suggests that the mussels do not serve as long-term reservoir for the bacterium. There was no evidence of a multiplication of the bacterium in the digestive tissue of the mussels.

Some of the bacteria taken up by the blue mussels passed the digestive system without being digested. Live bacteria were present in faeces samples collected in the experimental tank $11 \mathrm{~d}$ after exposure, since cod became infected after injection of a suspension prepared from faecal samples. The Francisella noatunensis-positive faeces particles represent a possible source of transmission, as they may be devoured by organisms on the next trophic level in a marine food chain. Such passage has been shown from bivalves experimentally contaminated with infectious pancreatic virus to prawns (Mortensen 1993).

Francisella noatunensis was observed inside haemocytes in some of the mussels sampled; with IHC, however, since the mussels eventually became $F$. noatunensis-negative, prolonged survival in haemocytes is unlikely. An interesting observation is the intense IHC signal in the cytoplasm of symbiotic ciliates in the blue mussel gills. It has previously been demonstrated that $F$. tularensis survives in bacterivorous amoebae, ciliates, and nanoflagellates, suggesting protists may play a role in the environmental survival of Francisella spp. (Abd et al. 2003, Thelaus et al. 2009). Also, a novel F. noatunensis subspecies, Candidatus F. noatunensis subsp. endociliophora, has been detected as a symbiont in the marine ciliate Euplotes raikovi (Schrallhammer et al. 2011).

In our experiments, Francisella noatunensis was not transmitted from blue mussels to cod during cohabitation. Similar experiments carried out with Aeromonas salmonicida and freshwater mussels indicate that this bacterium is present and able to cause disease at cohabitation; however, after a depuration period of between 10 and $15 \mathrm{~d}$, no transmission of the disease were detected (Starliper 2005). Immunohistochemistry of the $F$. noatunensis contaminated mussels revealed that only a limited amount of the bacteria filtrated during challenge were present at Days 11 and 22. In addition to low levels of infectious bacteria, bacteria might have been bound up in sedimented faecal pellets and thus not transmitted to cod.

We observed that samples from unexposed control mussels (tissues in Expts 1 and 3; fecal homogenate in Expt 2) produced positive signals with the Fc50 assay in real-time RT-PCR. However, tissue or fecalpellet homogenates from these did not produce Francisella noatunensis infections in cod when injected, as did the corresponding homogenates from exposed mussels. Also the IHC of the control mussels were negative. We were unable to amplify $F$. noatunensis DNA from selected samples (lowest $C_{\mathrm{t}}$ ). Hence our experimental data does not indicate that the Fc50 assay has detected $F$. noatunensis subsp. noatunensis infective to cod, but these observations remain unexplained. Wild cod in southern Norway may suffer from francisellosis (Ottem et al. 2008), so the possibility that mussels collected from nature have been exposed is omnipresent. However, several recent reports suggest that additional Francisella spp. occur in the marine environment (Petersen et al. 2009, Steinum et al. 2009, Schrallhammer et al. 2011). Occurrence of related species in seawater may further complicate the use of real-time RT-PCR to detect $F$. noatunensis in water samples, as well as in filtering invertebrates (see Colquhoun \& Duodu 2011). The present observations suggest that the Fc50 assay detect bacteria other than F. noatunensis subsp. noatunensis, present in the blue mussels collected.

The fate of Francisella noatunensis in blue mussels differs from that of Renibacterium salmoninarum (cf. Paclibare et al. 1994) since infective bacteria are released in an aggregated fashion through the mussel faeces. However, our evidence strongly suggests that a significant fraction of $F$. noatunensis is digested by the mussels, hence a degree of clearing of the water for the contagion occur. This fraction may be higher when the mussels are exposed to lower and likely more natural concentrations of the bacterium. Still, Francisella spp. are adapted to intracellular survival and parasitism, and other reservoirs of epizootiological importance may occur among the diverse invertebrate fauna that may be associated with cod aquaculture. 
Trophic transmission pathways may exist between bacterivores such as ciliates and mussels, other invertebrates such as decapods and unsuitable and suitable fish hosts, and further research is needed to understand the normal life cycle of this bacterium in nature.

Acknowledgements. Thanks are due to Ingrid U. Fiksdal, Hari Rudra, Rolf H. Olsen, and Cecilie Skår for technical assistance and comments on the manuscript, and to Linda Andersen for providing the stock of Halobacterium salinarum. This study was funded by the Norwegian Research Council and the Norwegian Fishery and Aquaculture Industry Research Fund.

\section{LITERATURE CITED}

Abd H, Johansson T, Golovliov I, Sandström G, Forsman M (2003) Survival and growth of Francisella tularensis in Acanthamoeba castellanii. Appl Environ Microbiol 69: 600-606

Alfjorden A, Jansson E, Johansson K (2006) A systemic granulomatous inflammatory disease in wild Atlantic cod, Gadus morhua associated with a bacterium of the genus Francisella. DIPnet 44:2

Berrada ZL, Telford SR (2010) Diversity of Francisella species in environmental samples from Martha's Vineyard, Massachusetts. Microb Ecol 59:277-283

Birkbeck TH, McHenery JG (1982) Degradation of bacteria by Mytilus edulis. Mar Biol 72:7-15

Broekhuijsen M, Larsson P, Johansson A, Byström M and others (2003) Genome-wide DNA microarray analysis of Francisella tularensis strains demonstrates extensive genetic conservation within the species but identifies regions that are unique to the highly virulent $F$. tularensis subsp. tularensis. J Clin Microbiol 41:2924-2931

Colquhoun D, Duodu S (2011) Francisella infections in farmed and wild aquatic organisms. Vet Res 42:1-15

Colquhoun D, Zerihun A, Mikalsen J (2008) Francisella spp. infections in farmed and wild fish. ICES CM 2008/D:07

> Doré WJ, Lees DN (1995) Behavior of Escherichia coli and male-specific bacteriophage in environmentally contaminated bivalve molluscs before and after depuration. Appl Environ Microbiol 61:2830-2834

> Duodu S, Colquhoun D (2010) Monitoring the survival of fish-pathogenic Francisella in water microcosms. FEMS Microbiol Ecol 74:534-541

Forsman M, Nyrén A, Sjöstedt A, Sjökvist L, Sandström G (1995) Identification of Francisella tularensis in natural water samples by PCR. FEMS Microbiol Ecol 16:83-92

Kamaishi T, Miwa S, Goto E, Matsuyama T, Oseko N (2010) Mass mortality of giant abalone Haliotis gigantea caused by a Francisella sp. bacterium. Dis Aquat Org 89: 145-154

> McHenery JG, Birkbeck TH (1985) Uptake and processing of cultured microorganisms by bivalves. J Exp Mar Biol Ecol 90:145-163

Meyers T (1984) Marine bivalve mollusks as reservoirs of viral finfish pathogens: significance to marine and anadromous finfish aquaculture. Mar Fish Rev 46:14-17

Mikalsen J, Olsen AB, Rudra H, Moldal T and others (2009) Virulence and pathogenicity of Francisella philomiragia subsp. noatunensis for Atlantic cod, Gadus morhua L., and laboratory mice. J Fish Dis 32:377-381

Mortensen SH (1993) Passage of infectious pancreatic necrosis virus (IPNV) through invertebrates in an aquatic food-chain. Dis Aquat Org 16:41-45

Mortensen S, Hjeltnes B, Rødseth O, Krogsrud J, Christie K (1990) Infectious pancreatic necrosis virus serotype N1, isolated from Norwegian halibut (Hippoglossus hippoglossus), turbot (Scophthalmus maximus) and scallops (Pecten maximus). Bull Eur Assoc Fish Pathol 10:42-43

Mortensen SH, Bachere E, Legall G, Mialhe E (1992) Persistence of infectious pancreatic necrosis virus (IPNV) in scallops Pecten maximus. Dis Aquat Org 12:221-227

Nylund A, Ottem KF, Watanabe K, Karlsbakk E, Krossøy B (2006) Francisella sp. (Family Francisellaceae) causing mortality in Norwegian cod (Gadus morhua) farming. Arch Microbiol 185:383-392

> Nylund S, Nylund A, Watanabe K, Arnesen CE, Karlsbakk E (2010) Paranucleospora theridion n. gen., n. sp. (Microsporidia, Enterocytozoonidae) with a life cycle in the salmon louse (Lepeophtheirus salmonis, Copepoda) and Atlantic salmon (Salmo salar). J Eukaryot Microbiol 57:95-114

> Olsen AB, Mikalsen J, Rode M, Alfjorden A and others (2006) A novel systemic granulomatous inflammatory disease in farmed Atlantic cod, Gadus morhua L., associated with a bacterium belonging to the genus Francisella. J Fish Dis 29:307-311

Olsvik PA, Kristensen T, Waagbø R, Tollefsen KE, Rosseland BO, Toften H (2006) Effects of hypo- and hyperoxia on transcription levels of five stress genes and the glutathione system in liver of Atlantic cod Gadus morhua. J Exp Biol 209:2893-2901

Ottem KF, Nylund A, Karlsbakk E, Friis-Møller A, Krossøy B (2007) Characterization of Francisella sp., GM2212, the first Francisella isolate from marine fish, Atlantic cod (Gadus morhua). Arch Microbiol 187:343-350

$>$ Ottem KF, Nylund A, Isaksen TE, Karlsbakk E, Bergh $\varnothing$ (2008) Occurrence of Francisella piscicida in farmed and wild Atlantic cod, Gadus morhua L., in Norway. J Fish Dis 31:525-534

>ttem KF, Nylund A, Karlsbakk E, Friis-Møller A, Kamaishi $\mathrm{T}$ (2009) Elevation of Francisella philomiragia subsp. noatunensis Mikalsen et al. (2007) to Francisella noatunensis comb. [nov. syn. Francisella piscicida Ottem et al. (2008) syn. nov.] and characterization of Francisella noatunensis subsp. orientalis subsp. nov., two important fish pathogens. J Appl Microbiol 106:1231-1243

Paclibare JO, Evelyn TPT, Albright LJ, Prosperiporta L (1994) Clearing of the kidney disease bacterium Renibacterium salmoninarum from seawater by the blue mussel Mytilus edulis, and the status of the mussel as a reservoir of the bacterium. Dis Aquat Org 18:129-133

Petersen JM, Carlson J, Yockey B, Pillai S and others (2009) Direct isolation of Francisella spp. from environmental samples. Lett Appl Microbiol 48:663-667

Prieur D, Mével G, Nicolas J, Plusquellec A, Vigneulle M (1990) Interactions between bivalve molluscs and bacteria in the marine environment. In: Barnes $H$, Barnes $M$, Ansell A, Gibson R, Pearson T (eds) Oceanography and marine biology, Vol 28. Aberdeen University Press, Oban, p 277-352

Richards GP (1988) Microbial purification of shellfish: a review of depuration and relaying. J Food Prot 51: $218-251$ 
Riisgard HU (1988) Efficiency of particle retention and filtration rate in 6 species of northeast American bivalves. Mar Ecol Prog Ser 45:217-223

Sandlund N, Torkildsen L, Magnesen T, Mortensen S, Bergh $\varnothing$ (2006) Immunohistochemistry of great scallop Pecten maximus larvae experimentally challenged with pathogenic bacteria. Dis Aquat Org 69:163-173

Schrallhammer M, Schweikert M, Vallesi A, Verni F, Petroni G (2011) Detection of a novel subspecies of Francisella noatunensis as endosymbiont of the ciliate Euplotes raikovi. Microb Ecol 61:455-464

Shaw BL, Battle HI (1957) The gross and microscopic anatomy of the digestive tract of the oyster Crassostrea virginica (Gmelin). Can J Zool 35:325-347

Skår CK, Mortensen S (2007) Fate of infectious salmon anaemia virus (ISAV) in experimentally challenged blue mussels Mytilus edulis. Dis Aquat Org 74:1-6

Ståhlberg A, Håkansson J, Xian X, Semb H, Kubista M (2004) Properties of the reverse transcription reaction in mRNA quantification. Clin Chem 50:509-515

Editorial responsibility: David Bruno,

Aberdeen, UK
Starliper CE (2005) Quarantine of Aeromonas salmonicidaharboring ebonyshell mussels (Fusconaia ebena) prevents transmission of the pathogen to brook trout (Salvelinus fontinalis). J Shellfish Res 24:573-578

Steinum T, Sjåstad K, Falk K, Kvellestad A, Colquhoun DJ (2009) An RT PCR-DGGE survey of gill associated bacteria in Norwegian seawater reared Atlantic salmon suffering proliferative gill inflammation. Aquaculture 293: 172-179

Thelaus J, Andersson A, Mathisen P, Forslund AL, Noppa l, Forsman M (2009) Influence of nutrient status and grazing pressure on the fate of Francisella tularensis in lakewater. FEMS Microbiol Ecol 67:69-80

Zerihun MA, Feist SW, Bucke D, Olsen AB, Tandstad NM, Colhoun DJ (2011) Francisella noatunensis subsp. noatunensis is the aetiological agent of visceral granulomatosis in wild Atlantic cod Gadus morhua. Dis Aquat Org 95:65-71

Zobell CF, Feltham CB (1938) Bacteria as food for certain marine invertebrates. J Mar Res 1:312-327

Submitted: July 12, 2011; Accepted: November 17, 2011 Proofs received from author(s): February 1, 2012 